\title{
Facile Synthesis of Propranolol and Novel Derivatives
}

\author{
Vy Anh Tran $\mathbb{D}^{1,2}$ Nguyen Hai Tai Tran, ${ }^{3}$ Long Giang Bach $\mathbb{D}^{4},{ }^{4}$ Trinh Duy Nguyen, ${ }^{5}$ \\ Thi Thuong Nguyen, ${ }^{5}$ Tan Tai Nguyen ${ }^{(D)},{ }^{6}$ Thi Anh Nga Nguyen $\mathbb{D D}^{7}{ }^{7}$ The Ky Vo, ${ }^{8}$ \\ Thu-Thao Thi Vo $\mathbb{D}^{2}$ and Van Thuan Le $\mathbb{D}^{2,9}$ \\ ${ }^{1}$ Institute of Research and Development, Duy Tan University, Danang 550000, Vietnam \\ ${ }^{2}$ Faculty of Environmental and Chemical Engineering, Duy Tan University, Danang 550000, Vietnam \\ ${ }^{3}$ Department of Chemical Engineering, Ho Chi Minh City University of Technology, Ho Chi Minh City, Vietnam \\ ${ }^{4}$ NTT Hi-Tech Institute, Nguyen Tat Thanh University, 300A Nguyen Tat Thanh, Ward 13, District 4, Ho Chi Minh City, Vietnam \\ ${ }^{5}$ Center of Excellence for Green Energy and Environmental Nanomaterials (CE GrEEN), Nguyen Tat Thanh University, \\ 300A Nguyen Tat Thanh, District 4, Ho Chi Minh City 755414, Vietnam \\ ${ }^{6}$ Department of Materials Science, School of Applied Chemistry, Tra Vinh University, Tra Vinh City 87000, Vietnam \\ ${ }^{7}$ Biomaterials and Nanotechnology Research Group, Faculty of Applied Sciences, Ton Duc Thang University, \\ Ho Chi Minh City, Vietnam \\ ${ }^{8}$ Department of Chemical Engineering, Industrial University of Ho Chi Minh City, 12 Nguyen Van Bao, Go Vap, \\ Ho Chi Minh City, Vietnam \\ ${ }^{9}$ Center for Advanced Chemistry, Institute of Research and Development, Duy Tan University, Da Nang 550000, Vietnam
}

Correspondence should be addressed toVy Anh Tran; trananhvy@duytan.edu.vn,Thu-Thao Thi Vo; vothuthaobd@gmail.com, and Van Thuan Le; levanthuan3@duytan.edu.vn

Received 2 May 2020; Revised 14 July 2020; Accepted 27 July 2020; Published 24 August 2020

Academic Editor: Matthias D’hooghe

Copyright (C) 2020 Vy Anh Tran et al. This is an open access article distributed under the Creative Commons Attribution License, which permits unrestricted use, distribution, and reproduction in any medium, provided the original work is properly cited.

\begin{abstract}
Propranolol is one of the first medications of the beta-blocker used for antihypertensive drugs. This study reports the facile route for the synthesis of propranolol and its novel derivatives. Herein, propranolol synthesis proceeded from 1-naphthol and isopropylamine under mild and less toxic conditions. Novel propranolol derivatives were designed by reactions of propranolol with benzoyl chloride, pyridinium chlorochromate, and n-butyl bromide through esterification, oxidation reduction, and alkylation, respectively. The isolation and purity of compounds were conducted using column chromatography and thin-layer chromatography. Mass spectrometry and ${ }^{1} \mathrm{H}-\mathrm{NMR}$ spectroscopy were applied to identify new compounds structure. Propranolol derivatives from 2-chlorobenzoyl chloride (compound 3), 2-fluorobenzoyl chloride (compound 5), and especially acetic anhydride (compound 6) manifested high yields and significantly increased water solubility. Six semisynthetic propranolol derivatives promise to improve antioxidative and biological activities.
\end{abstract}

\section{Introduction}

Propranolol is one of the original medicines of the betablocker used to treat hypertension, tremors, angina, and cardiovascular disorders $[1,2]$. Besides, propranolol also is an effective and safe drug for treating migraine headaches, anxiety disorders, and infantile hemangiomas [3, 4]. Moreover, several studies have recently reported that patients receiving propranolol reduced the risk of neck and head, colon, stomach, and prostate cancers [5-7].
Methods for the synthesis of propranolol were investigated by using enzymes to resolve intermediate compounds [8-10]. However, the enzyme strategy did not show effective manufacturing because of several limitations, i.e., multistep, low overall yields (lower than 30\%), and use of hazardous and costly reagents $[10,11]$. Besides, the hydrogenation of the chiral metal of the intermediate by polymer-supported reagent was used [12]. Nevertheless, the methods used to catalyze metal salts are often complex and costly. In addition, the synthesis efficiency and the selectivity of propranolol are 
not high $[10,13]$. Thus, the development of propranolol derivatives to improve biopharmaceutical and therapeutic features, as well as to reduce the first level of metabolism, is absolutely necessary. To minimize the extension of the firstpass conjugation, many prodrugs of propranolol have been synthesized in the investigation of new high-acting lipophilic derivatives. Amongst them, homologous acyl ester prodrugs of propranolol, e.g., O-acetyl and O-propionyl carboxylic acid ester, were discovered with higher bioavailability and lipophilicity than those of propranolol [14-16].

In this study, the synthesis of propranolol was conducted between 1-naphthol and isopropylamine under mild, less toxic conditions and fast reaction time. Novel propranolol derivatives were formed by reactions at the C-13 and N-15 position through esterification reactions between propranolol and 2-bromobenzoyl chloride, 2-chlorobenzoyl chloride, and 2-fluorobenzoyl chloride. The oxidation and alkylation reactions between propranolol and pyridinium chlorochromate and n-butyl bromide were also investigated. Novel derivatives were achieved in high yields and significantly enhanced water solubility.

\section{Methods and Experiment}

2.1. Chemical Materials. Sulphuric acid, iodine, chloroform, dichloromethane, tetrahydrofuran (THF), potassium carbonate, 2-fluorobenzoyl chloride, 2-bromobenzoyl chloride, 2-chloromobenzoyl chloride, 1-naphthol, isopropylamine, and epichlorohydrin were purchased from Sigma Aldrich. Thin-layer chromatography (TLC) silica gel $60 \mathrm{~F}_{254}$ was bought from Merck (Germany, $20.0 \times 10.0 \mathrm{~cm}$ ). Silica gel 230-400 mesh for column chromatography was purchased from HiMedia (India). Water and ethanol (HPLC grade) were used without additional purification. Other chemicals were used as the highest possible quality as received. Glassware was cleaned using an acidic solution of $\mathrm{HNO}_{3}$ : $\mathrm{HCl}(1: 3 \mathrm{v} / \mathrm{v})$ and then washed several times with deionized water.

\subsection{Methods of Characterization}

2.2.1. Thin-Layer Chromatography (TLC). $5 \mu \mathrm{L}$ of sample and standard solutions was dropped on a TLC plate, which was immersed in ethyl acetate:hexane system (mobile phase) at different ratios. The moving of the mobile phase was finished until it reached the highest limitation of the TLC plate. The separated TLC plate was dried at room temperature (RT) for $30 \mathrm{~min}$ and observed under visible light or UV light.

2.2.2. Column Chromatography (CC). The CC method was applied for fractionation and purification of the synthesized products by using columns filled with silica gel of 230-400 mesh and glass columns with different diameters of $1.5,2$, and $5 \mathrm{~cm}$ and lengths of 30 and $40 \mathrm{~cm}$. The mobile phase of hexane : ethyl acetate at different ratios was used to separate propranolol and its desired derivatives.
2.2.3. Mass Spectrometry (MS). The determination and detection of fragments and molecular ions from propranolol and its derivatives were carried out by MicroOTOF-Q 10187 mass spectrometer (Bruker, Germany).

2.2.4. Proton Nuclear Magnetic Resonance Spectroscopy $\left({ }^{1} \mathrm{H}\right.$ NMR). The structure of propranolol and its derivatives was identified by ${ }^{1} \mathrm{H}-\mathrm{NMR}$ spectra recorded on a Bruker Ultrashield 500 spectrometer (Germany).

2.3. Synthesis of Propranolol Derivatives. To enhance the antioxidation and biological activity, target moieties at C-13 and N-15 of propranolol were investigated for further reactions. New derivatives were produced by reactions from propranolol with benzoyl chloride (esterification), with pyridinium chlorochromate (oxidation-reduction), and with n-butyl bromide (alkylation) (Figure 1).

2.3.1. Synthesis of Propranolol from 1-Naphthol and Isopropylamine. Propranolol was synthesized from reaction between 1-naphthol and isopropylamine according to reactions described in Figure 2. Typically, $1.25 \mathrm{~g}$ of 1-naphthol $(8.67 \mathrm{mM})$ was dissolved in $10 \mathrm{~mL}$ of ethanol: water $(9: 1)$, followed by adding $0.5 \mathrm{~g}$ of $\mathrm{KOH}$ into the above mixture under stirring for $30 \mathrm{~min}$. Next step, $4 \mathrm{~mL}$ of epichlorohydrin $(0.05 \mathrm{M})$ was drop-down until the color of the mixture changed to orange-yellow. After every $30 \mathrm{~min}$ of the reaction, the formation of propranolol and its derivatives was determined by TLC. The solvent of the reaction mixture was evaporated and the yellow-brown compound of oil form was obtained. Then, $50 \mathrm{~mL}$ of diethyl ether was added to the resulting product under shake condition, and the water was removed by $\mathrm{Na}_{2} \mathrm{SO}_{4}$ anhydrous. Next, the reaction mixture were isolated by $\mathrm{CC}$ using the mobile phase of hexane : ethyl acetate $(\mathrm{H}: \mathrm{E}) 6: 4$, resulting in collecting of $1.05 \mathrm{~g}(5.25 \mathrm{mM})$ of 2-((naphthalen-1-yloxy) methyl) oxirane (1a). Besides, two compounds of $\mathbf{1 b}$ were also obtained (Figure 2).

$1.05 \mathrm{~g}$ of compound 1a dissolved in $10 \mathrm{~mL}$ of methanol was added to $15 \mathrm{~mL}$ of isopropylamine $(12 \mathrm{mM})$ and stirred at $45^{\circ} \mathrm{C}$ until obtaining the yellow-brown solution $(48 \mathrm{~h})$ and solution was cooled to $5^{\circ} \mathrm{C}$. Then, $1.5 \mathrm{ml}$ of $\mathrm{HCl}(2 \mathrm{M})$ was dropped slowly into the resulting mixture, followed by adding $\mathrm{NaOH}$ (2 M) until white precipitate appeared. The precipitate was washed by water, isolated by CC using a mixture of $H: E=5: 5$. Finally, $0.738 \mathrm{~g}$ of 1 -(isopropylamino)-3-(naphthalen-1-yloxy) propan-2-ol (compound 2) or propranolol was collected (Figure 2).

2.3.2. Synthesis of Propranolol with 2-Chlorobenzoyl Chloride, 2-Bromobenzoyl Chloride, and 2-Flourobenzoyl Chloride (Compounds 3, 4, and 5). Briefly, $200 \mathrm{mg}$ of propranolol $(0.77 \mathrm{mM})$ was dissolved in $10 \mathrm{~mL} \mathrm{CHCl}_{3}$ at RT. Then, $300 \mathrm{mg}$ of 2 -chlorobenzoyl chloride $(1.71 \mathrm{mM})$ or $300 \mathrm{mg}$ (1.37 mM) of 2-bromobenzoyl chloride or $300 \mathrm{mg}(1.89 \mathrm{mM})$ of 2-flourobenzoyl chloride was added to the propranolol mixture. Each reaction mixture was stirred and refluxed at 


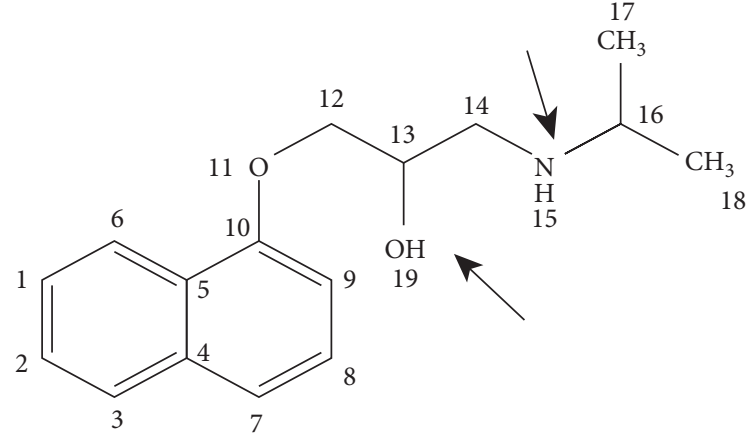

FIGURE 1: Chemical structure of propranolol (1-(1-methylethylamino)-3-(1-naphthyloxy)propan-2-ol) and reactions at the $\mathrm{OH}$ group at $\mathrm{C}-13$ position and $\mathrm{N}-15$ position.

$50 \mathrm{C}$ for $24 \mathrm{~h}$. After every hour, the formation of a new compound from each reaction was identified by TLC. Each reaction mixture was isolated ( 3 times) by a CC system with the mobile phase of water and ethyl acetate. Next step, $3 \mathrm{~mL}$ of saturated $\mathrm{NaHCO}_{3}$ solution was added to the mixture under stirring condition. The reaction mixture was filtered, solvent was evaporated under vacuum, and the resulting product was purified by CC using a solvent system of $H$ : $E 7$ : 3. Finally, $136 \mathrm{mg} / 150 \mathrm{mg} / 115 \mathrm{mg}$ of compound $3 / 4 / 5$ were obtained, respectively (Figure 3).

2.3.3. Synthesis of Propranolol with Anhydride Acetic (Compound 6). $100 \mathrm{mg}$ of acetic anhydride $(1.11 \mathrm{mM})$ was added into $200 \mathrm{mg}$ of the propranolol $(0.77 \mathrm{mM})$ in $10 \mathrm{~mL}$ $\mathrm{CHCl}_{3}$. The reaction mixture was refluxed at $45^{\circ} \mathrm{C}$ for 24 hours followed by examined TLC every hour. The reaction mixture was isolated by CC three times. Then, $5 \mathrm{~mL}$ of saturated $\mathrm{NaHCO}_{3}$ solution was added into the reaction mixture to isolate ethyl acetate and remove water by $\mathrm{Na}_{2} \mathrm{SO}_{4}$ anhydrous. The new compound of the reaction was isolated by CC using solvent mixture of $H: E 7: 3$. The result obtained $170 \mathrm{mg}$ of compound 6 (Figure 4).

2.3.4. Synthesis of Propranolol with Pyridinium Chlorochromate (PCC) (Compound 7). $40 \mathrm{mg}$ of PCC was mixed with $200 \mathrm{mg}$ of propranolol $(0.77 \mathrm{mM})$ in $15 \mathrm{~mL}$ of $\mathrm{CH}_{2} \mathrm{Cl}_{2}$. Then, reaction mixture was refluxed at $40^{\circ} \mathrm{C}$ for $20 \mathrm{~h}$. After ending the reaction, the mixture was filtered, solvent was removed, and the resulting product was purified by CC using a mobile system of dichloromethane: methanol $(D: M) 8: 2$. Finally, the result of reaction obtained $180 \mathrm{mg}$ of 1 -(isopropylamino)-3-(naphthalen-1-yloxy) propan-2-one compound 7 (Figure 5).

2.3.5. Synthesis of Propranolol with $n$-Butyl Bromide (Compound 8). $1.06 \mathrm{~g}$ of $\mathrm{K}_{2} \mathrm{CO}_{3}, 0.2 \mathrm{~g}$ of the propranolol $(0.77 \mathrm{mM})$, and $210 \mathrm{mg}$ of n-butyl bromide $(1.54 \mathrm{mM})$ were put in $10 \mathrm{~mL}$ of acetonitrile under stirring for $30 \mathrm{~min}$. The reaction proceeded for $24 \mathrm{~h}$ at $\mathrm{RT}$. The reaction mixture was isolated using CC with mobile phase of $D: M 8: 2.130 \mathrm{mg}$ of the compound $\mathbf{8}$ was collected (Figure 6).
2.4. Aqueous Solubility Procedure. Aqueous solubility was measured for each compound in phosphate buffered saline (PBS, pH 7.4) [17]. Briefly, each equivalent was incubated at a final concentration of $200 \mu \mathrm{M}$ in $2 \%$ DMSO with the appropriate aqueous medium under shaking for $24 \mathrm{~h}$ at RT. The compound identification was done via HPLC with photodiode array detection.

\section{Results and Discussion}

3.1. Other Propranolol Synthesis Methods. As shown in Figure 7(a), (S)-propranolol was prepared by using $\mathrm{Zn}\left(\mathrm{NO}_{3}\right)_{2} /(+)$-tartaric acid for the resolution of the terminal epoxide. This method was conducted at $75^{\circ} \mathrm{C}$ in enantioselectivity through a kinetic resolution of intermediate $\alpha$-naphthyl glycidyl ether [10]. However, methods of using metal salts as a catalyst for the synthesis of propranolol are often complicated and costly. Besides, there was low selectivity in isomer separation (S)-propranolol. The nucleophilic ring opening of epoxides was preceded by the perchloric acid supported silica matrix $\left(\mathrm{HClO}_{4}-\mathrm{SiO}_{2}\right)$. Besides, microwave-assisted $\mathrm{HClO}_{4}-\mathrm{SiO}_{2}$ system was investigated for efficient and cost-effective synthesis processing [18] (Figure $7(\mathrm{~b})$ ).

\subsection{Results of Mass Spectrometry and ${ }^{1} H$-NMR Spectra}

3.2.1. 2-((Naphthalen-1-yloxy)methyl)oxirane (Compound 1a). Brownish-yellow oil form, ${ }^{1} \mathrm{H}-\mathrm{NMR} \quad(500 \mathrm{MHz}$, $\left.\mathrm{CDCl}_{3}\right), 2.86(\mathrm{dd}, J=5.0,2.7 \mathrm{~Hz}, 1 \mathrm{H}), 2.98(\mathrm{dd}, J=5.0$, $4.1 \mathrm{~Hz}, 1 \mathrm{H}), 3.51$ (ddt, $J=5.7,4.2,2.8 \mathrm{~Hz}, 1 \mathrm{H}), 4.14(\mathrm{dd}$, $J=11.0,5.6 \mathrm{~Hz}, 1 \mathrm{H}), 4.40(\mathrm{dd}, J=11.0,3.0 \mathrm{~Hz}, 1 \mathrm{H}), 6.84-8.41$ $(7 \mathrm{H}, \mathrm{m})$ of naphthalene.

HRMS (ESI-MS, $m / z),(\mathrm{M}+\mathrm{Na})^{+},\left[\mathrm{C}_{23} \mathrm{H}_{12} \mathrm{O}_{2}+\mathrm{Na}\right]^{+}$, theory: 223.0748, experiment: 200.0748 .

3.2.2. Two Isomers of 1-Chloro-3-(naphthalen-1-yloxy) propan-2-ol and 2-Chloro-3-(naphthalen-1-yloxy)propan-1ol (Compound 1b). ${ }^{1} \mathrm{H}-\mathrm{NMR}\left(500 \mathrm{MHz}, \mathrm{CDCl}_{3}\right), 3.87$ (dd, $J=11.3,5.7 \mathrm{~Hz}, 1 \mathrm{H}), 3.94(\mathrm{dd}, J=11.3,5.0 \mathrm{~Hz}, 1 \mathrm{H}), 4.35-4.26$ $(\mathrm{m}, 2 \mathrm{H}), 4.41(\mathrm{p}, J=5.3 \mathrm{~Hz}, 1 \mathrm{H}), 4.53-4.45(\mathrm{~m}, 4 \mathrm{H}), 4.76$ (p, $J=5.3 \mathrm{~Hz}, 1 \mathrm{H}), 6.90-8.33(7 \mathrm{H}, \mathrm{m})$ of naphthalene.

HRMS (ESI-MS, $m / z),(\mathrm{M}+\mathrm{Na})^{+},\left[\mathrm{C}_{13} \mathrm{H}_{13} \mathrm{ClO}_{2}+\mathrm{Na}\right]^{+}$, theory: 260.1628 , experiment: 236.69 .

3.2.3. Propranolol (Compound 2). White powder, yield: $70.3 \%,{ }^{1} \mathrm{H}-\mathrm{NMR}\left(500 \mathrm{MHz}, \mathrm{CDCl}_{3}\right), 1.16$ (dd, $J=6.3,1.5 \mathrm{~Hz}$, $6 \mathrm{H}), 2.91$ (ddd, $J=12.3,8.3,6.9 \mathrm{~Hz}, 2 \mathrm{H}), 3.06$ (dd, $J=12.2$, $3.5 \mathrm{~Hz}, 1 \mathrm{H}), 4.20-4.14(\mathrm{~m}, 1 \mathrm{H}), 4.27-4.21$ (m, 2H), 6.85-8.27 $(7 \mathrm{H})$ of naphthalene.

HRMS (ESI-MS, $m / z),(\mathrm{M}+\mathrm{Na})^{+},[\mathrm{C} 16 \mathrm{H} 21 \mathrm{NO} 2+\mathrm{Na}]^{+}$, theory: 282.1469, experiment: 259.1666.

3.2.4. Two Isomers of 2-Chloro-N-(2-hydroxy-3-(naphthalene-1-yloxy)propyl)-N-isopropylbenzamide and 1-(Isopropylamino)-3-(naphthalene-1-yloxy)-propan-2-yl 2Chlorobenzoate (Compound 3). White amorphous powder, 
<smiles>Oc1cccc2ccccc12</smiles><smiles>ClCC1CO1</smiles><smiles>OCCC(O)O</smiles><smiles>c1ccc2c(OCC3CO3)cccc2c1</smiles><smiles>CC(C)NCC(O)COc1cccc2ccccc12</smiles>

Figure 2: The scheme illustrates the synthesis reaction of propranolol from 1-naphthol and isopropylamine.<smiles>CC(C)NCC(O)COc1cccc2ccccc12</smiles><smiles>CC(C)NCC(COc1cccc2ccccc12)OC(=O)c1ccccc1C(F)(F)F</smiles>

Figure 3: The scheme describes the synthesis of propranolol with (i) 2-chlorobenzoyl chloride; (ii) 2-bromobenzoyl chloride; (iii) 2-flourobenzoyl chloride, at conditions of $\mathrm{CHCl}_{3}$ and $\mathrm{NaHCO}_{3}$ at $50^{\circ} \mathrm{C}$ for $24 \mathrm{~h}$. 


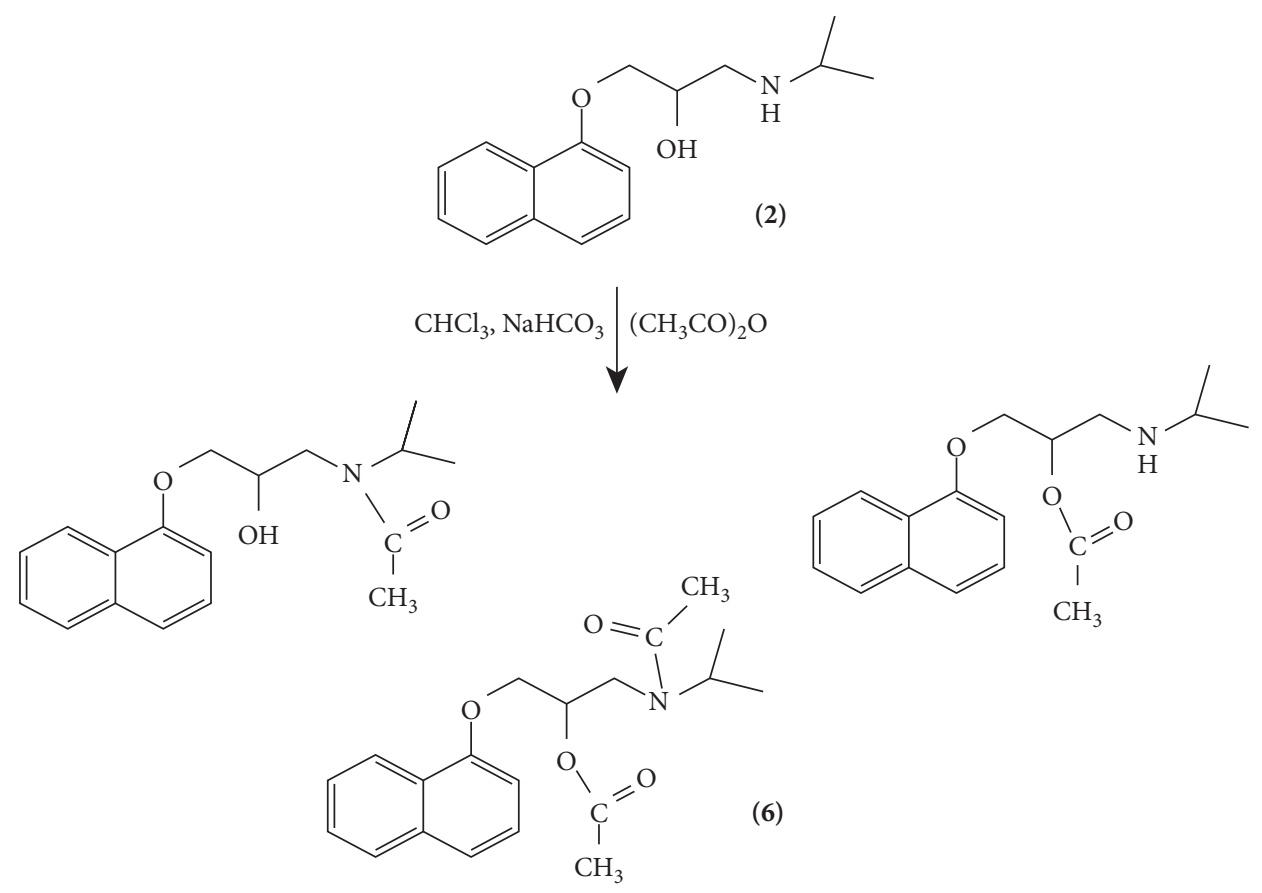

Figure 4: The scheme describes the synthesis of propranolol with anhydride acetic at conditions of $\mathrm{CHCl}_{3}$ and $\mathrm{NaHCO}_{3}$ at $45^{\circ} \mathrm{C}$ for $24 \mathrm{~h}$.

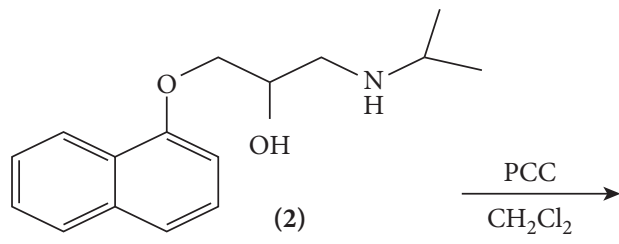<smiles>CC(C)NCC(=O)COc1cccc2ccccc12</smiles>

1-(Isopropylamino)-3-(naphthalen1-yloxy)propan-2-one

FIgURE 5: The scheme describes the synthesis process between propranolol and pyridinium chlorochromate in presence of $\mathrm{CH}_{2} \mathrm{Cl}_{2}$, at $40^{\circ} \mathrm{C}$ for $20 \mathrm{~h}$.

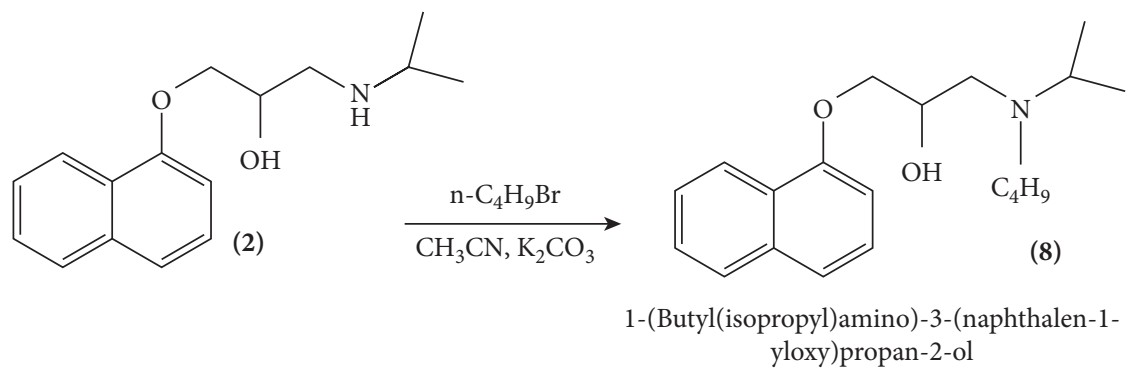

FIgURE 6: The scheme describes the synthesis of propranolol with n-butyl bromide (compound 8) at conditions of $\mathrm{CH}_{3} \mathrm{CN}$ for $24 \mathrm{~h}$.

yield: $68.0 \%,{ }^{1} \mathrm{H}-\mathrm{NMR}\left(500 \mathrm{MHz}, \mathrm{CDCl}_{3}\right), 1.11-1.36$ (dd, $J=22.8,6.6 \mathrm{~Hz}, 12 \mathrm{H}), 3.85-3.70(\mathrm{~m}, 4 \mathrm{H}), 3.94(\mathrm{ddd}, J=30.5$, $14.6,8.1 \mathrm{~Hz}, 2 \mathrm{H}), 4.18$ (ddd, $J=24.2,9.5,7.7 \mathrm{~Hz}, 2 \mathrm{H}), 4.31$ (dd, $J=9.4,4.5 \mathrm{~Hz}, 2 \mathrm{H}), 4.49-4.40(\mathrm{~m}, 1 \mathrm{H}), 6.91-8.25(11 \mathrm{H})$ of naphthalene and 2-chlorobenzoyl.

HRMS (ESI-MS, m/z), $(\mathrm{M}+\mathrm{Na})^{+},[\mathrm{C} 23 \mathrm{H} 24 \mathrm{ClNO} 3+\mathrm{Na}]^{+}$, theory: 420.1329 , experiment: 397.14 .
3.2.5. Two Isomers of 2-Bromo-N-(2-hydroxy-3-(naphthalene-1-yloxy)propyl)-N-isopropylbenzamide and 1-(Isopropylamino)-3-(naphthalene-1-yloxy)-propan-2-yl 2Bromobenzoate (Compound 4). White amorphous powder, yield: $73.1 \%,{ }^{1} \mathrm{H}-\mathrm{NMR}\left(500 \mathrm{MHz}, \mathrm{CDCl}_{3}\right), 1.10-1.39$ (d, $J=6.6 \mathrm{~Hz}, 312 \mathrm{H}), 3.69-3.85(\mathrm{~m}, 4 \mathrm{H}), 3.94$ (ddd, $J=39.7$, 14.6, $8.0 \mathrm{~Hz}, 2 \mathrm{H}), 4.19$ (ddd, $J=33.1,9.5,7.7 \mathrm{~Hz}, 2 \mathrm{H}), 4.32$ 


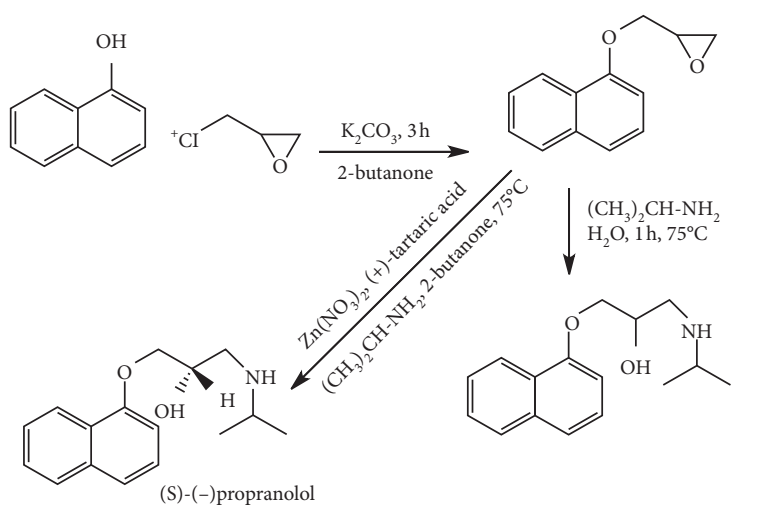

(a)
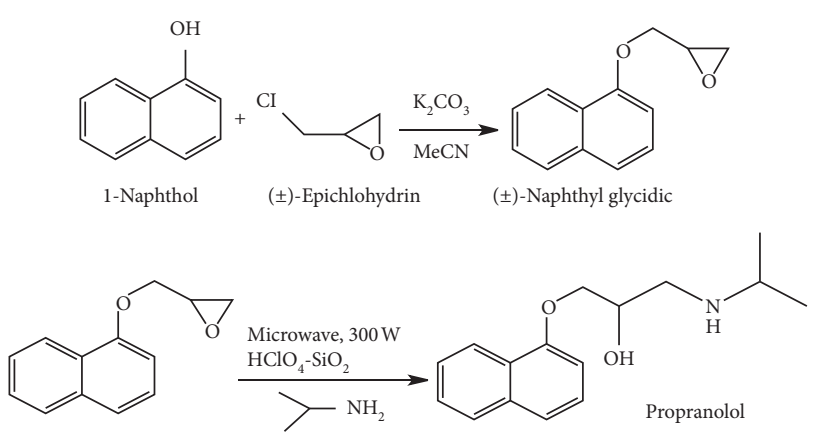

(b)

FIgURe 7: (a) Synthesis of propranolol used a catalyst of tartaric acid and metal salts; (b) ring opening of epoxides employing thiophenol under microwave conditions and synthesis of propranolol using silica perchloric acid catalyst.

(dd, $J=9.4,4.5 \mathrm{~Hz}, 2 \mathrm{H}), 4.39-4.51(\mathrm{~m}, 2 \mathrm{H}), 6.91-8.25(11 \mathrm{H}$, $\mathrm{m})$ of naphthalene and 2-chlorobenzoyl.

HRMS (ESI-MS, $m / z), \quad(\mathrm{M}+\mathrm{Na})^{+}\left({ }^{79 / 81} \mathrm{Br}\right)$, $[\mathrm{C} 23 \mathrm{H} 24 \mathrm{BrNO} 3+\mathrm{Na}]^{+}\left({ }^{79 / 81} \mathrm{Br}\right)$, theory: $464.0834 / 466.0813$.

3.2.6. Two Isomers of 2-Fluoro-N-(2-hydroxy-3-(naphthalene-1-yloxy)propyl)-N-isopropylbenzamide and 1-(Isopropylamino)-3-(naphthalene-1-yloxy)-propan-2-yl 2Fluorobenzoate (Compound 5). Dark blue liquid, yield: $57.4 \%,{ }^{1} \mathrm{H}-\mathrm{NMR}\left(500 \mathrm{MHz}, \mathrm{CDCl}_{3}\right), 0.86-1.40(\mathrm{~m}, 12 \mathrm{H})$, $3.36-3.51(\mathrm{~m}, 4 \mathrm{H}), 3.65(\mathrm{~d}, J=5.8 \mathrm{~Hz}, 2 \mathrm{H}), 4.11(\mathrm{dd}, J=9.6$, $6.1 \mathrm{~Hz}, 2 \mathrm{H}), 4.29-4.18(\mathrm{~m}, 2 \mathrm{H}), 4.52(\mathrm{~d}, J=3.8 \mathrm{~Hz}, 2 \mathrm{H})$, 6.69-8.28 (m, 20H) of naphthalene and 2-chlorobenzoyl.

HRMS (ESI-MS, $m / z),(\mathrm{M}+\mathrm{H})^{+},\left[\mathrm{C}_{23} \mathrm{H}_{25} \mathrm{FNO}_{3}+\mathrm{H}\right]^{+}$, theory: 382.1820 , experiment: 381.4488 .

3.2.7. Two Isomers of N-(2-Hydroxy-3-(naphthalene-1-yloxy) propyl)-N-isopropylacetamide and 1-(Isopropylamino)-3(naphthalen-1-yloxy)propan-2-yl Acetate (Compound 6). White amorphous powder, yield: $85.0 \%,{ }^{1} \mathrm{H}-\mathrm{NMR}$ $\left(500 \mathrm{MHz}, \mathrm{CDCl}_{3}\right), 1.24(\mathrm{dd}, J=8.8,6.2 \mathrm{~Hz}, 6 \mathrm{H}), 1.33$ (dd, $J=17.3,6.7 \mathrm{~Hz}, 6 \mathrm{H}), 2.14-2.25(6 \mathrm{H}, \mathrm{m}), 3.43(1 \mathrm{H}, \mathrm{dd}$, $J=14.3,6.9 \mathrm{~Hz}), 3.83(1 \mathrm{H}, \mathrm{dd}, J=14.4,5.3 \mathrm{~Hz}), 4.06(1 \mathrm{H}, \mathrm{p}$, $J=6.5 \mathrm{~Hz}), 4.19-4.36(2 \mathrm{H}, \mathrm{m}), 6.81-8.21(1 \mathrm{H}, \mathrm{m}, \mathrm{H}-9)$.

HRMS (ESI-MS, $m / z),(\mathrm{M}+\mathrm{H})^{+},[\mathrm{C} 23 \mathrm{H} 18 \mathrm{NO} 3+\mathrm{H}]^{+}$, theory: 302.1748, experiment: 301.1700.

3.2.8. 1-(Isopropylamino)-3-(naphthalene-1-yloxy)propan-2one (Compound 7). White amorphous powder, yield: $90.2 \%$, ${ }^{1} \mathrm{H}-\mathrm{NMR}\left(500 \mathrm{MHz}, \mathrm{CDCl}_{3}\right), 1.50(\mathrm{dd}, J=9.5,6.4 \mathrm{~Hz}, 6 \mathrm{H})$, $3.33-3.25(\mathrm{~m}, 1 \mathrm{H}), 3.41(\mathrm{~d}, J=13.1 \mathrm{~Hz}, 1 \mathrm{H}), 3.53-3.46(\mathrm{~m}$, $1 \mathrm{H}), 4.12(\mathrm{dd}, J=9.6,5.6 \mathrm{~Hz}, 1 \mathrm{H}), 4.22(\mathrm{dd}, J=9.5,3.9 \mathrm{~Hz}$, $1 \mathrm{H}), 6.81-8.21$ (1H, m, H-9).

HRMS (ESI-MS, m/z), $(\mathrm{M}+\mathrm{H})^{+},[\mathrm{C} 16 \mathrm{H} 19 \mathrm{NO} 2+\mathrm{H}]^{+}$, theory: 258.3349, experiment: 257.3326 .

3.2.9. 1-(Butyl(isopropyl)amino)-3-(naphthalene-1-yloxy) propan-2-ol (Compound 8). Brownish-yellow liquid, yield: $65.5 \%,{ }^{1} \mathrm{H}-\mathrm{NMR}\left(500 \mathrm{MHz}, \mathrm{CDCl}_{3}\right), 0.98(\mathrm{t}, J=7.3 \mathrm{~Hz}, 2 \mathrm{H})$, $1.15(\mathrm{~d}, J=6.7 \mathrm{~Hz}, 2 \mathrm{H}), 1.06(\mathrm{~d}, J=6.6 \mathrm{~Hz}, 2 \mathrm{H}), 1.27(\mathrm{t}$, $J=6.2 \mathrm{~Hz}, 2 \mathrm{H}), 1.44-1.33(\mathrm{~m}, 2 \mathrm{H}), 1.58-1.50(\mathrm{~m}, 1 \mathrm{H}), 2.57$ $(\mathrm{dt}, J=8.1,6.0 \mathrm{~Hz}, 1 \mathrm{H}), 2.79-2.66(\mathrm{~m}, 1 \mathrm{H}), 3.17-3.07(\mathrm{~m}$, $1 \mathrm{H}), 4.21-4.12(\mathrm{~m}, 2 \mathrm{H}), 4.25(\mathrm{p}, J=4.1 \mathrm{~Hz}, 1 \mathrm{H})$.

HRMS (ESI-MS, $m / z),(\mathrm{M}+\mathrm{H})^{+},[\mathrm{C} 22 \mathrm{H} 29 \mathrm{NO} 2+\mathrm{H}]^{+}$, theory: 340.4787 , experiment: 339.4764 .

3.3. Reaction Mechanisms. Propranolol has been synthesized according to the drug manufacturing process from 1naphthol and isopropylamine. Besides the formation of propranolol, two intermediate compounds $\mathbf{1 a}$ and $\mathbf{1 b}$ also were found. From the pristine propranolol, seven new derivatives have been synthesized from the compound (2) to (8), in which every compound of $3,4,5$, and 6 produced only two isomers, different from the theory of 3 isomers (as shown in Table 1). The new compounds structures were confirmed by MS and ${ }^{1} \mathrm{H}-\mathrm{NMR}$ spectra, indicating that these compounds were entirely suitable. The propranolol derivatives were obtained in high yields from $57.4 \%$ to $90.2 \%$.

The mechanism of the esterification reactions for formation compounds $\mathbf{3}, \mathbf{4}$, and $\mathbf{5}$ is very close. The $\mathrm{OH}$ group of propranolol is reacted with the activating group $(\mathrm{Cl} / \mathrm{Br} / \mathrm{F})$ replaced by the alcohol moiety. The reaction continues by either an addition-elimination through attack of the incoming nucleophile at the $\mathrm{sp}^{2}$ carbon atom or an elimination-addition chain. $\mathrm{Cl} / \mathrm{Br} / \mathrm{F}$ is a good leaving group to maximize the efficiency of the esterification protocol by minimizing electron donation to the carbonyl functional group. Besides, when anhydrides are employed in the esterification reaction, $50 \%$ of the acid component is lost because only one of the acid moieties is transformed to the desired ester. Therefore, this approach was used for simple, inexpensive carboxylic acids with a low degree of functionalization, including acetic anhydride (compound 6) $[19,20]$.

In the oxidation reaction of propranolol using pyridinium chlorochromate, the first step is the attack of oxygen on the chromium to form the $\mathrm{Cr}-\mathrm{O}$ bond. Secondly, a proton on the $\mathrm{OH}$ is transferred to one of the oxygen atoms of the chromium, possibly through the intermediacy of the 
TABLE 1: Summary of propranolol derivatives.<smiles>c1ccc2c(OCC3CO3)cccc2c1</smiles><smiles>OCC(Cl)COc1cccc2ccccc12</smiles>

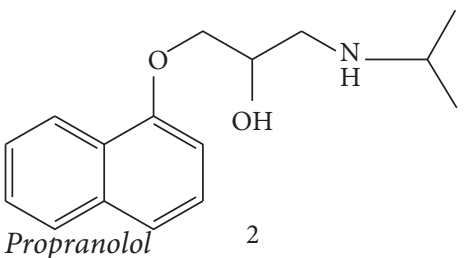<smiles>CC(C)N(CC(O)COc1cccc2ccccc12)C(=O)c1ccccc1Cl</smiles>

2-Chloro-N-(2-hydroxy-3-(naphthalen-1-yloxy)propyl)-Nisopropylbenzamide<smiles>CC(C)N(CC(O)COc1cccc2ccccc12)C(=O)c1ccccc1Br</smiles>

2-Bromo-N-(2-hydroxy-3-(naphthalen-1-yloxy)propyl)-Nisopropylbenzamide<smiles>CC(C)N(CC(O)COc1cccc2ccccc12)C(=O)c1ccccc1F</smiles>

2-Flouro-N-(2-hydroxy-3-(naphthalen-1-yloxy)propyl)-Nisopropylbenzamide<smiles>OC(CCl)COc1cccc2ccccc12</smiles>

1-Chloro-3-(naphthalen-1-yloxy)propan-2-ol<smiles>CC(C)NCC(COc1cccc2ccccc12)OC(=O)c1ccccc1Cl</smiles>

1-(Isopropylamino)-3-(naphthalen-1-yloxy)propan-2-yl 2chlorobenzoate<smiles>CC(C)NCC(COc1cccc2ccccc12)OC(=O)c1ccccc1Br</smiles>

1-(Isopropylamino)-3-(naphthalen-1-yloxy)propan-2-yl 2bromobenzoate<smiles>CC(C)NCC(COc1cccc2ccccc12)OC(=O)c1ccccc1F</smiles>

1-(Isopropylamino)-3-(naphthalen-1-yloxy)propan-2-yl 2fluorobenzoate 
TABLE 1: Continued.<smiles>CC(=O)N(CC(O)COc1cccc2ccccc12)C(C)C</smiles>

N-(2-Hydroxy-3-(naphthalen-1-yloxy)propyl)-N-isopropylacetamide<smiles>CC(C)NCC(=O)COc1cccc2ccccc12</smiles>

1-(Isopropylamino)-3-(naphthalen-1-yloxy)propan-2-one hydrate<smiles>CC(=O)OC(CNC(C)C)COc1cccc2ccccc12</smiles>

1-(Isopropylamino)-3-(naphthalen-1-yloxy)propan-2-yl acetate<smiles>C=C(/C=C/C)OCC(O)CN(CCCCCC)C(C)C</smiles>

(8)

1-(Butyl(isopropyl)amino)-3-(naphthalen-1-yloxy)propan-2-ol<smiles>[R]C([R])OCCCC[Te](=O)([O-])([O-])Cl</smiles><smiles>c1cc[nH+]cc1</smiles><smiles>[R]C([R])O[PH](=O)([O-])Cl</smiles><smiles>c1cc[nH+]cc1</smiles>

Propranolol
derivative<smiles></smiles>

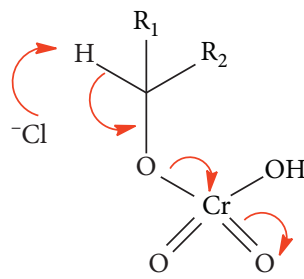<smiles>[R]C(C)C</smiles>

$\downarrow \mathrm{H}^{+}$transfer

(a)

FIGURE 8: Continued. 


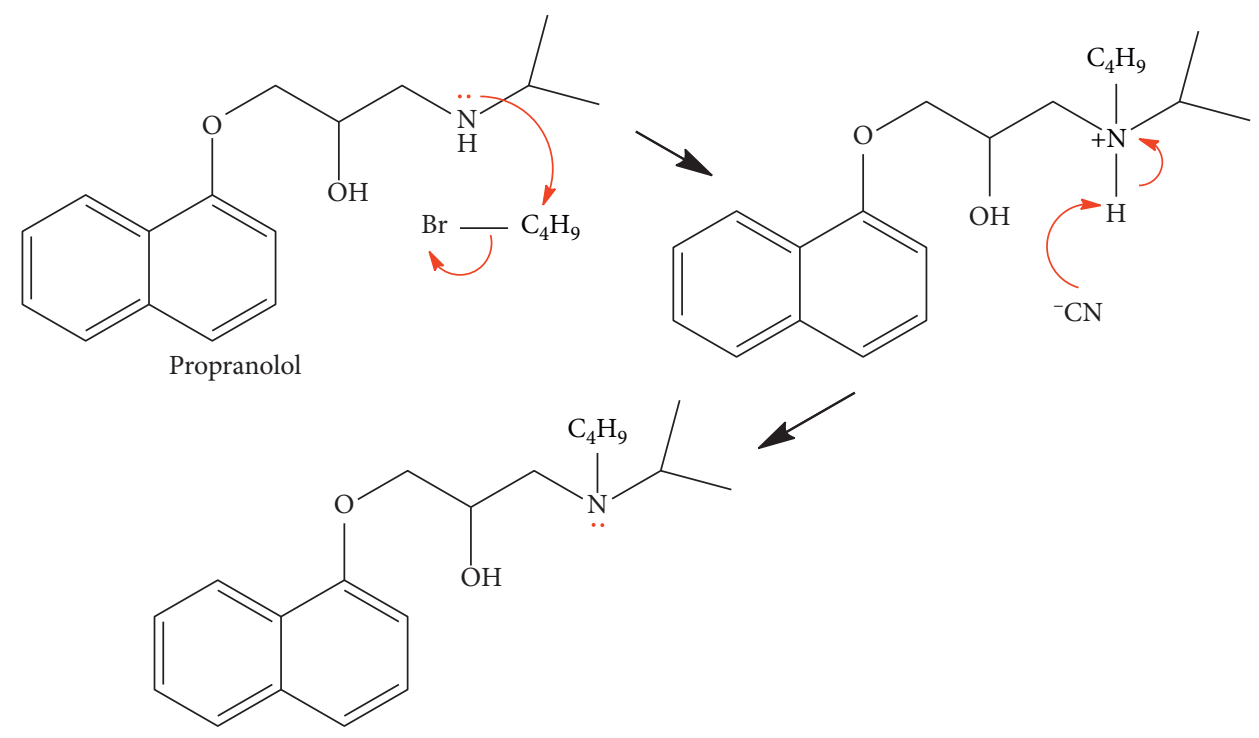

(b)

FIGURE 8: (a) Oxidation reaction mechanism of propranolol using pyridinium chlorochromate; (b) amine alkylation reaction mechanism between propranolol and n-butyl bromide.

TABLE 2: The solubility of propranolol derivatives.

\begin{tabular}{lc}
\hline Compound & Water solubility $(\mu \mathrm{g} / \mathrm{mL})$ \\
\hline $\mathbf{2}$ & 61.7 \\
$\mathbf{3}$ & 92.4 \\
$\mathbf{4}$ & 74.7 \\
$\mathbf{5}$ & 112.5 \\
$\mathbf{6}$ & 243.6 \\
$\mathbf{7}$ & 55.4 \\
$\mathbf{8}$ & 51.3 \\
\hline
\end{tabular}

pyridinium salt. A chloride ion is then displaced to form what is known as a chromate ester. The C-O double bond is formed when a base removes the proton on the carbon adjacent to the oxygen. It is also necessary for pyridine to be used as the base here, but only very small amounts of the deprotonated component would be found under such acidic conditions. The electrons from the $\mathrm{C}-\mathrm{H}$ bond move to form the $\mathrm{C}=\mathrm{O}$ bond of compound 7 , and in the process, the $\mathrm{Cr}-\mathrm{O}$ bond is broken, and $\operatorname{Cr}(\mathrm{VI})$ becomes $\mathrm{Cr}(\mathrm{IV})$ as shown in Figure 8(a) [21].

$\mathrm{N}$ of propranolol functions as the nucleophile and attacks the electrophilic $\mathrm{C}$ of $\mathrm{n}$-butyl bromide, displacing the bromide and creating the new $\mathrm{C}-\mathrm{N}$ bond. Then the base (excess amine) deprotonates the positive $\mathrm{N}$ (ammonium) center, creating the alkylation product [22], so-called compound 8 (Figure $8(\mathrm{~b})$ ).

3.4. Solubility of Propranolol Derivatives. The water solubility of these propranolol derivatives was investigated (as shown in Table 2). The water solubility of propranolol was $61.7 \mu \mathrm{g} / \mathrm{mL}$. In contrast, new derivatives from acetone and n-butyl groups were slightly less soluble due to the involvement of hydrophilic functional supplement groups. Propranolol derivatives from 2-chlorobenzoyl chloride (3), 2-fluorobenzoyl chloride (5), and especially acetic anhydride (6) showed a significant increase toward water solubility compared to propranolol. The water solubility of other compounds was not much changed compared to that of propranolol.

\section{Conclusions}

Polypharmacology remains one of the significant difficulties in drug improvement, and it initiates novel avenues to create the next generation of drugs. A route for the synthesis of propranolol has been developed under simple, inexpensive, and mild reaction conditions. Remarkably, we successfully synthesized seven novel propranolol derivatives at the C-13 and N-15 of propranolol, obtained in high yields. The water solubility of compounds 3,5 , and $\mathbf{6}$, corresponding to products of propranolol with 2-chlorobenzoyl chloride, 2fluorobenzoyl chloride, and acetic anhydride, was improved significantly. The present study shows that the synthesized propranolol derivatives represent promising new compounds to enhance antioxidative, biological activities and the need for investigation in the near future.

\section{Data Availability}

The data used to support the findings of this study are included in the article.

\section{Conflicts of Interest}

The authors declare that there are no conflicts of interest regarding the publication of this article. 


\section{Acknowledgments}

This research was funded by Duy Tan University, Da Nang city, Vietnam, and Vietnam National Foundation for Science and Technology Development (NAFOSTED) under grant no. 104.05-2019.03.

\section{References}

[1] S. Hardison, W. Wan, and K. M. Dodson, "The use of propranolol in the treatment of subglottic hemangiomas: a literature review and meta-analysis," International Journal of Pediatric Otorhinolaryngology, vol. 90, pp. 175-180, 2016.

[2] S. A. Steenen, A. J. Van Wijk, G. J. Van der Heijden, R. Van Westrhenen, J. De Lange, and A. De Jongh, "Propranolol for the treatment of anxiety disorders: systematic review and meta-analysis," Journal of Psychopharmacology (Oxford, England), vol. 30, no. 2, pp. 128-139, 2016.

[3] A. V. Srinivasan, "Propranolol: a 50-year historical perspective," Annals of Indian Academy of Neurology, vol. 22, no. 1, pp. 21-26, 2019.

[4] R. Čižmáriková, L. Habala, J. Valentová, and M. Markuliak, "Survey of pharmacological activity and pharmacokinetics of selected $\beta$-adrenergic blockers in regard to their stereochemistry," Applied Sciences, vol. 9, no. 4, p. 625, 2019.

[5] W. H. Frishman, "Beta-adrenergic receptor blockers in hypertension: alive and well," Progress in Cardiovascular Diseases, vol. 59, no. 3, pp. 247-252, 2016.

[6] P.-Y. Chang, W.-Y. Huang, C.-L. Lin et al., "Propranolol reduces cancer risk: a population-based cohort study," Medicine, vol. 94, no. 27, Article ID e1097, 2015.

[7] E. M. Yee, E. Pasquier, G. Iskander, K. Wood, D. S. Black, and N. Kumar, "Synthesis of novel isoflavene-propranolol hybrids as anti-tumor agents," Bioorganic \& Medicinal Chemistry, vol. 21, no. 7, pp. 1652-1660, 2013.

[8] S. Batra and R. Bhushan, "Methods and approaches for determination and enantioseparation of (RS)-propranolol," Biomedical Chromatography, vol. 33, no. 1, Article ID e4370, 2019.

[9] M. Sasaki, P. E. North, J. Elsey et al., "Propranolol exhibits activity against hemangiomas independent of beta blockade," Npj Precision Oncology, vol. 3, no. 1, p. 27, 2019.

[10] N. Singh, A. Kumar, and R. Singh, "Concise synthesis of (S)(-)-propranolol: using acid catalysed kinetic resolution," Journal of Chemical and Pharmaceutical Research, vol. 4, no. 12, pp. 5111-5113, 2012.

[11] X. Wu, A. Noda, H. Noda, and Y. Imamura, "Side-chain metabolism of propranolol: involvement of monoamine oxidase and aldehyde reductase in the metabolism of N-desisopropylpropranolol to propranolol glycol in rat liver, Comparative biochemistry and physiology," Toxicology \& Pharmacology: CBP, vol. 129, no. 4, pp. 361-368, 2001.

[12] A. Gharib, M. Jahangir, and M. Roshani, "Synthesis of (S)(-)-Propranolol by using Cs2.5H0.5PW12O40 nanocatalyst as green, eco-friendly, reusable, and recyclable catalyst, synthesis and reactivity in inorganic, metal-organic," Synthesis and Reactivity in Inorganic, Metal-Organic, and Nano-Metal Chemistry, vol. 45, no. 3, pp. 350-355, 2015.

[13] S. A. M. Yassin and K. F.-A. Samarrai, "Ratio spectrum derivative quantitative analysis of propranolol and diazipam in combind pharmaceutical mixtures," International Journal of Research in Pharmaceutical Sciences, vol. 10, no. 4, pp. 3657-3664, 2019.
[14] H.-K. Han and G. L. Amidon, "Targeted prodrug design to optimize drug delivery," AAPS Pharmaceutical Sciences, vol. 2, no. 1, p. E6, 2000.

[15] R. Čižmáriková, S. Chudáčiková, J. Valentová, and A. Némethy, "Synthesis and enantioseparation of derivatives of propranolol," Acta Facultatis Pharmaceuticae Universitatis Comenianae, vol. 59, no. 1, pp. 5-13, 2012.

[16] M. N. Lokhande, M. U. Chopade, D. N. Bhangare, and M. D. Nikalje, "Asymmetric synthesis of propranolol, naftopidil and (R)-monobutyrin using a glycerol desymmetrization strategy," Journal of the Brazilian Chemical Society, vol. 24, pp. 406-409, 2013.

[17] J.-M. Hwang, T. Oh, and T. Kaneko, "Design, synthesis, and structure-activity relationship studies of tryptanthrins as antitubercular agents," Journal of Natural Products, vol. 76, no. 3, pp. 354-367, 2013.

[18] Y. L. N. Murthy, B. S. Diwakar, B. Govindh, R. Venu, and K. Nagalakshmi, "Silica perchloric acid matrix supported ring opening of epoxide under microwave radiation," Chemical Science Transactions, vol. 2, no. 3, pp. 805-812, 2013.

[19] P. Siengalewicz, J. Mulzer, and U. Rinner, "6.09 synthesis of esters and lactones," in Comprehensive Organic Synthesis II, P. Knochel, Ed., pp. 355-410, Elsevier, Amsterdam, Netherlands, Second edition, 2014.

[20] M. Jia, L. Jiang, F. Niu, Y. Zhang, and X. Sun, "A novel and highly efficient esterification process using triphenylphosphine oxide with oxalyl chloride," Royal Society Open Science, vol. 55, no. 5, Article ID 171988, 2018.

[21] F. A. Luzzio, R. W. Fitch, W. J. Moore, and K. J. Mudd, “A facile oxidation of alcohols using pyridinium chlorochromate/ silica gel," Journal of Chemical Education, vol. 76, no. 7, p. 974, 1999.

[22] W. S. Emerson, The Preparation of amines by reductive alkylation, Organic Reactions, pp. 174-255, 2011. 